\title{
THE RULING COMMUNIST PARTY OF VIETNAM IN THE CURRENT SITUATION
}

\author{
Nguyen Thi Tram \\ Academy of Politics Region II \\ 99 Man Thien, Hiep Phu Ward, Thu Duc City, Ho Chi Minh City, Vietnam \\ E-mail: tramnguyenhvct@gmail.com
}

\begin{abstract}
The aim of this study is to learn about the ruling Communist Party of Vietnam in the current situation. The study shows that in terms of leading, the Communist Party of Vietnam has affirmed to be the decisive factor in all victories of the Vietnamese revolutions. This paper seeks to address the following questions: 1/ prove the achievements of Vietnam obtained since the Communist Party of Vietnam is in power; 2/ generalize the views and theories on the ruling party, the ruling Communist Party, and the ruling Communist Party of Vietnam; 3/ present the results and discussion on the ruling Communist Party of Vietnam in the current situation. For these purposes, a variety of methods are used including analysis and synthesis, deduction and induction, abstraction and generalization, logic, history, and comparison to come to the findings and recommendations of the study.
\end{abstract}

Keywords: Ruling Party, The Ruling Communist Party, The Ruling Communist Party of Vietnam, Current Situation.

\section{INTRODUCTION}

One of the most significant current discussions in politics is "ruling party". The ruling party in Vietnam is the Communist party of Vietnam which is the product of the inevitable combination of Marxism - Leninism with the workers' movement and the patriotic movement of Vietnam. With a history of more than 90 years since its establishment and 76 years of ruling, the Communist Party of Vietnam has affirmed to be the decisive factor in all victories of the Vietnamese revolution. In each revolutionary period, the method of governance and the requirement to improve the Party's ruling capacity are always issues posed by specific conditions which always need to change, develop and improve. Establishing the ruling method of the Party in the current situation is an objective requirement of the cause of renewal, and accelerating industrialization and modernization of the country and international integration is an important solution to strengthen the ruling position of the Party and the vigorous vitality of socialism.

In terms of ruling, the Communist Party of Vietnam has completed many tasks of national construction and development. A social opinion survey on "The results of 5 years of implementing the Resolution of the 12th National Party Congress" conducted by the Institute for Research on Public Opinion - Central Propaganda Department showed that the Communist Party of Vietnam has focused on building and rectifying the Party, improving the Party's capacity and fighting strength; prevent and reverse the deterioration of political ideology, morality, lifestyle, internal "self-evolution" and "self-transformation" manifestations (86\%); disease prevention (85\%); 
maintaining security, politics, social order and safety (81\%); expressing the legitimate will and aspirations of the people in the guidelines and policies of the Party and State (80\%); consolidate and strengthen national defense and security, firmly protect the independence and sovereignty of the Fatherland (79\%); promote the people's mastery, strengthen great national unity (79\%); implement the foreign policy of independence, self-reliance, multilateralization, diversification, initiative and active international integration, enhancing Vietnam's position and prestige in the region and in the world (76\%) ); well implement guidelines and policies towards ethnic and religious people $(73 \%)$; restructuring agriculture, formulating new rural policies $(72 \%)$; ensure social security, improve social welfare, well implement policies towards people with meritorious services (72\%); anti-corruption (71\%) (Communist Party of Vietnam, 2021).

The contents and methods of ruling of the Party are major issues that the Party has determined and implemented to maintain and affirm the Party's ruling position and role. In the current situation, the world and regional situation is evolving very quickly, which is complicated to predict. The country is facing many opportunities and advantages as well as many difficulties and challenges, many new problems have to be solved, especially new challenges due to the impact of the Covid-19 pandemic and the global economic crisis. Cadres, party members, and people place their trust and expectation in the correct and strong decisions of the Party so that our country can develop faster and more sustainably.

For the above reasons, the issue of "the ruling Communist Party of Vietnam in the current context" attracts the author's concern about this research topic.

\section{LITERATURE REVIEW}

In recent years, there has been an increasing amount of literature on "ruling party". The ruling party is the concept referring to the political party in the period of gaining the right to establish and use the government apparatus to accomplish the goals and tasks of the ruling party under the constitution and law. The term "ruling party" is a term used in both capitalist and socialist countries. In capitalist countries, this term refers to the party that wins the election through competitive elections, obtaining a majority of seats in the parliament, and having the right to form a government. Before having a ruling party, there had been a state, a constitution, a legal system, and the ruling party had to comply with the constitution and laws of these countries. In the book, "Some issues about the ruling party and the opposition party in American political life", Nguyen Thi Hanh gave an overview of the history of the formation and development of the party in American political life. The book also mentions the operating methods of the ruling party and the opposition party. The author has also analyzed assessed the ruling party and the opposition party. The author argues that to become the ruling party and maintain its ruling position, the party must conduct and win the election to become the majority party and the ruling party (Hanh, 2012).

The ruling Communist Party is the party that has gained its ruling status through the revolutionary struggle of the proletariat or the people's democratic national revolution, overthrowing the government apparatus of the exploiting class, establishing a state a new model the state of the working class and the working people to realize the Party's noble purpose of building the country towards socialism and communism.

Regarding the ruling Communist Party of Vietnam, since the victory of the August Revolution in 1945, establishing the Democratic Republic of Vietnam, our Party has become the ruling party and the only party in power to lead the State and socio-political organizations to carry out two strategic tasks: to successfully build socialism and liberate the country, and to defend the socialist Vietnamese Fatherland. President Ho Chi Minh was the first to use the term "ruling party", 
he stated: "Our party is the ruling party. Every cadre and party member must be imbued with revolutionary morality, truly thrift, integrity, impartiality, and justice." (Minh, 1995, p.510). The Charter of the Communist Party of Vietnam affirms: "The Communist Party of Vietnam is the ruling Party, leading the State and society. The Party regularly improves its ruling capacity and leadership effectiveness, while strongly promoting the role, initiative, creativity, and responsibility of other organizations in the political system." (Communist Party of Vietnam, 2011, pp.88-89).

A recent study on "Building a ruling party, some practical experiences of renovation in Vietnam", at the theoretical seminar between the Communist Party of Vietnam and the Communist Party of China on building the ruling party (Trong, 2004), General Secretary Nguyen Phu Trong stated that the ruling party means the party leading the government, making all activities of the government express and implement the ideology and lines of that Party in line with the stance and serving the interests of the class and class that the party represents. The textbook of the Ho Chi Minh National Academy of Politics also confirmed the characteristics of the ruling Communist Party of Vietnam (Ho Chi Minh National Academy of Politics, 2018). First of all, the Communist Party of Vietnam became the ruling Party after the Party led the people to fight for national liberation and class liberation. Since its establishment, the Communist Party of Vietnam has been the revolutionary leading force in the struggle to regain the independence of the Fatherland and overthrow the feudal colonial regime to take power into the hands of the working people. During that long and arduous struggle, the working people have always acknowledged that the revolutionary line set forth by the Party is correct and that cadres and party members have always been at the forefront of the revolutionary struggle, fighting and sacrificing for national independence and the interests of the working classes and people. Secondly, the political mission of the Communist Party of Vietnam has changed basically. From no government to having a government is a fundamental turning point of the revolution, a qualitatively new development in the historical mission of the working class. When the government has not yet been won, the Party's main task is to lead the people in the struggle to overthrow the old regime the state apparatus of the exploiting class; When taking power, the Party's first task is to establish the people's revolutionary state and build a new society, including the task of protecting the revolutionary achievements. Thirdly, the Communist Party of Vietnam has a socialist rule of law state of the people, by the people, for the people. The socialist rule of law state is a main, sharp tool through which the Party exercises its leadership over society. Fourthly, the Party's leadership method has changed radically: Having a government, the central task of the Party for the whole society is to lead socio-economic development and other fields of the country. Fifthly, our Party is the only Party to lead the State and society towards socialism, which is a prominent feature that governs all activities of the Party. Sixthly, the Party has led the country to develop a socialist-oriented market economy in the condition that the socialist rule of law state is in the process of building and perfecting. The socialist-oriented market economy under the leadership of the Party - in both theory and practice - is a new, difficult and complex issue. That requires our Party to explore and experiment to form and lead the State and society to properly operate the socialist-oriented market economy.

A study "Perceiving the concepts of the ruling party and the leading party in our country today" by Dong and Duc (2011), the authors showed an approach to the concept of the ruling party. Since then, these authors have analyzed quite deeply and comprehensively, and they stated that the ruling party and the leading party are two concepts that are not identical with each other (Dong, 2013). In another study by Nguyen Huu Dong, "The Party incarnates into the State in the renewal of our Party's ruling method", the author has clarified the concept of "the Party incarnates into the 
State" in the condition that there is only one party in power in our country. The author found that "the party incarnates into the State" is a concept that refers to the "hiding" of the power of the ruling party into the "shell" of the power of the state, exercising domination and orientation towards the state, mainly through the role of individual elite party members of the party to realize the goals and program set forth by the party (Dong, 2013). In his research with the topic "The only party in power - an inevitable product of socio-political reality in Vietnam", Pham Ngoc Quang, Bang argues quite convincingly, proving that the Communist Party of Vietnam has become the only ruling party since the August Revolution in 1945 thanks to the successes that the Communist Party of Vietnam has led the people during more than 80 years of existence and development both in times of war and in peacetime. In particular, the author has proved that the element of "national independence associated with socialism" that our Party pursues is the value system that carries throughout the Vietnamese revolution, both in the past, present, and the future (Quang, 2010)

Also discussing the renewal of the Party's leadership method, with the topic "Innovating the Party's leadership method in the current ruling Party conditions - the problem is posed", Ho Ba Tham confirmed that, in the current situation, our Party is facing quite basic problems such as power corruption, system errors related to the Party's leadership-ruling method. This is the cause leading to political, ideological, moral, and lifestyle corruption of a large number of cadres and party members, reducing the prestige of the Party among the people (Tham, 2012). Sharing the same opinion, in the article "On the Party's ruling method", Vu Van Hien discussed the concept of the Party's ruling method. According to the author, the ruling Communist Party of Vietnam is the Party in power, building the government apparatus to adopt the system of government to lead the country towards socialism (Hien, 2015). In another study "The ruling Communist Party of Vietnam and the Party's current method of ruling", from the scientific approach and convincing presentation, Ngo Huy Tiep introduced the concept of the ruling Communist Party of Vietnam. At the same time, the author gave in-depth analysis and clarification of the concept of the ruling Communist Party of Vietnam; in which the author has introduced 4 contents affirming the role and ruling position of the Party: (1) The Party is the decisive factor for all victories of the revolutionary cause by the people; (2) The Party is responsible to the people and nation for the development of all aspects of the country; (3) The Party representing the nation establishes peaceful and friendly relations with other nations and peoples in the international community; (4) The Party is the subject of the close relationship between the Party and the people (Tiep, 2017). In another study "Some issues about the ruling Communist Party of Vietnam in new conditions" by Thang, the author has explained and clarified many issues about the ruling Communist Party of Vietnam in the new context. Firstly, it is the party's rule that is established by the people's mandate. Secondly, the party must raise its intellectual level, be more steadfast and creative in Marxism-Leninism and Ho Chi Minh's Thought. Thirdly, the Party must be clean and strong. Fourthly, it is necessary to continue to renew the leadership method of the Communist Party of Vietnam. Regarding the leadership method of the ruling Communist Party of Vietnam, according to the author, there is a very flexible "dynamic" nature even at each level (Thang, 2011). Specifying the method of implementing democracy, with the study "Practicing democracy in the condition of one ruling party", Nguyen Van Huyen stated that the problem of democracy in the condition of one ruling party is extremely important since taking advantage of Western political theory, hostile forces believe that the democratic condition in a political system is an opposing multi-party system (at least two parties). Therefore, to practice true democracy in the condition of a ruling party, the Party must first promote the implementation of democracy. Democracy is not only the life of the Party but also the 
life of society, without democracy, there would be no socialism, industrialization, modernization, and sustainable development (Huyen, 2014).

\section{Results}

\section{RESULTS AND DISCUSSION}

\section{The Preparation and Issuance of the Party's Resolutions and the Assignment of Organizations} and Officials in Charge of Implementing the Resolutions

The results of the study point out that the quality of program development, full-term working plan of the Party committees, and directing the advisory agencies to prepare necessary conditions for the formulation of resolutions, such as documents, materials, and means have been focused and enhanced. A possible explanation for this might be that it is necessary to renovate the formulation of draft resolutions, consult agencies, mass organizations, and party organizations. Currently, this activity is quite well-prepared: the Secretariat has issued many documents with up to 184 resolutions, directives, conclusions, regulations, plans, and guidelines. At the Provincial Party Committee, 7818 documents have been issued including 150 resolutions, 401 directives, 815 regulations, 553 programs, 1104 decisions, 144 regulations, 165 conclusions, 2493 plans, 201 projects, 1793 other documents (Communist Party of Vietnam, 2021, pp. 166-167). It is also essential to renovate the study, exchange, and decision on the topic of the resolution and the consideration and decision assigned to the agencies and organizations in charge of the draft resolution formulation project and the coordinating agencies. It needs to improve the quality of the conference to discuss and pass resolutions. It is necessary to renovate the assignment of officers in charge of each job to organize the implementation of the issued resolutions based on strictly implementing the regime of collective leadership and individuals in charge.

\section{Organize the Implementation of the Party's Resolutions}

Another finding was that the grasping of resolutions in party organizations, the political system, and the people, is renewed following the current situation. Mass media agencies have been directed to promptly propagate the Party's resolutions on the mass media. The Party has focused on directing the State to concretize and institutionalize resolutions, develop schemes, programs, and plans. The Party has implemented many pilot models on organizational structure, arrangement of administrative units at district and commune levels in terms of controlling power in cadre work and fighting against running for power; on the national defense strategy in cyberspace and the national cybersecurity strategy; strengthen the protection of the Party's ideological foundation, and fight against hostile wrong views in the new situation (Communist Party of Vietnam, 2021, p.166). This result may be explained by the fact that the implementation of the Party's resolutions plays a vital role in economic, cultural, and social development.

\section{Working Style and Manners}

The current study found that working style and manners have been carried out in the direction of expanding democracy, maintaining the discipline of the Party and strictly implementing the working regulations, building and well implementing the daily work program monthly, quarterly, annually in the direction of respecting the opinions of the people. Currently, the government is presiding over and coordinating with relevant agencies to receive 20233 turns of citizens. The localities have received 400097 turns of citizens. The Party committee has coordinated with the Fatherland Front and socio-political organizations to organize more than 90,000 dialogue conferences between the Party committees and authorities and the People (Communist Party of 
Vietnam, 2021, p. 204). The Party always clearly identifies the focus needs to be led. The regime of reporting and consulting on activities of the State, the Fatherland Front, and socio-political organizations in all fields of social life has been strictly maintained. The Party has practiced the style of connecting to reality, promptly solving problems that arise, talking in parallel with action, attaching importance to directing, checking, and summarizing practice.

\section{Organization and Staff Work}

On the question of organization and staff work, the study found that the organization and staff have been renewed and valued and identified as an important stage of their organization. The Party has reviewed and concretized the functions and tasks of organizations as a basis for arranging and consolidating the organization, apparatus, and officials of state agencies, the Fatherland Front, and socio-political organizations. Currently, through the review, there are still 29 contents that are not consistent between the state's law and the Party's regulations on organization and cadres. The percentage of young leaders and members has not yet reached the set target (Communist Party of Vietnam, 2021, p.196). The Party has strongly renovated the stages of personnel work: assessment, planning, appointment, election, the nomination of candidates, management, implementation of personnel policies, ensuring the correct selection and use of cadres, especially the heads of state agencies, the Fatherland Front and socio-political organizations. The Party has strongly renovated and strengthened the rational decentralization of cadre management in state agencies, the Fatherland Front, and socio-political organizations.

\section{Strongly Promote the Role of Party Organizations and the Vanguard and Exemplary Role of Party Members Working in State Agencies, the Fatherland Front, and Socio-Political Organizations}

Another important finding was that party organizations have been built strong to constantly improve leadership capacity and combat strength, uphold the spirit of struggle, self-criticism, and serious criticism against the negatives in party organizations and cadres, party members in state agencies, the Fatherland Front, and socio-political organizations in all fields of social life. The party has focused on renovating educational contents and forms, raising awareness and responsibility of party members for the renewal of the Party's leadership method. Party members must pioneer and model implementation of the Party's resolutions, the State's policies and laws, and the tasks of localities, agencies, and units. The Party has attached importance to creating favorable conditions for Party members to perform their assigned tasks well. At the same time, each party member must attract a large number of cadres, civil servants, public employees, and people to perform well the tasks of agencies, mass organizations, and localities (Ho Chi Minh National Academy of Politics, 2018)

\section{Bring into Full Play the Role of the State, the Fatherland Front, and Socio-Political Organizations Participating in the Renewal of the Party's Leadership Method}

An interesting finding was that the Party has had a mechanism to bring into play the role of the State, the Fatherland Front, and socio-political organizations to participate in the formulation of the Party's resolutions, the cadre work of the State, the Fatherland Front, and other political organizations. The Party has promoted the role of supervision and social criticism of the Fatherland Front and socio-political organizations in the activities of party organizations, government agencies, cadres, party members, and civil servants. With the promotion of the role of the State, the Fatherland Front and socio-political organizations participating in the renewal of the Party's 
leadership method have helped to improve the implementation of democracy. According to report No. 515-BC/BDVTW on the results of the implementation of the year of mass mobilization, in 2019, up to 478237 citizens came to state agencies to complain, denounce, petition, and report related to the rights and obligations of citizens (Communist Party of Vietnam, 2021, p. 204).

\section{Inspection and Supervision of Party Organizations and Party Members Working in State} Agencies, the Fatherland Front, and Socio-Political Organizations and Fields of Social Life

It is interesting to note that the inspection and supervision of organizations have been renewed and improved. Currently, Party committees at all levels have inspected 2,64920 party organizations and 1124146 party members. Party committees at all levels have supervised 193993 party organizations and 528652 party members; inspection committees at all levels have supervised 124469 party organizations and 185731 party members (Communist Party of Vietnam, 2021, p. 200). In general, this activity has focused on inspecting and supervising the awareness-raising and responsibilities of key leaders, officials, and party members regarding the position, role, and effects of the inspection, supervision, especially supervision over the leadership of the Party, state management, activities of state agencies; of cadres and civil servants in the party, government, mass organizations and in other fields of social life. The Party has renovated the content and form of inspection and supervision work.

\section{Discussion}

The study has pointed out that from theory to practice, the ruling Communist Party of Vietnam in the condition of developing a socialist-oriented market economy, building a socialist rule of law state, and international integration has proved its decisive role in leading Vietnam from one victory to another. At this point, the research author would like to offer 4 topics of exchange and discussion:

Firstly, the reality of the socialist-oriented renovation cause has posed the problem of having to insist on a single party in power, along with the expansion of democracy in the Party and society.

Secondly, implement the institution of a single party in power, build a socialist rule of law state, but do not implement the separation of powers and civil society which pose problems with the establishment and implementation of the Party's ruling content and methods.

Thirdly, the contingent of cadres and party members of the Party to exercise power from the central to the grassroots level must be built clean, with integrity, posing the problem of establishing and implementing the contents and methods of the party's leadership methods.

Fourthly, the practice requires improving the Party's ruling capacity. However, the theory of the ruling party in the context of developing a socialist-oriented market economy and a socialist rule of law state and international integration is not clear enough about the content, model, and mode of governance.

\section{CONCLUSION}

In conclusion, becoming the ruling party, the Communist Party of Vietnam has shown great achievements in leadership and building the state, the Vietnam Fatherland Front, and sociopolitical organizations in the political system. Specifically:

In Vietnam, the ruling Communist Party of Vietnam since its birth has always won the right to lead the revolution, and it has become the decisive factor in all the victory of the Vietnamese revolution. 
Becoming the ruling party, the Communist Party of Vietnam has had experienced many difficulties and challenges. During more than 76 years of ruling and 35 years of implementing the renovation (doi moi), its great achievements have affirmed its ruling position- the only ruling party.

The Communist Party of Vietnam has always actively led and directed theoretical research and practical summaries of the renovation process, especially the fundamental values of the Party, i.e. ideology, scientific and revolutionary values of Marxist-Leninist theory, and Ho Chi Minh's thought. The formulation and planning of strategic directions in socio-economic development and caring for the material and spiritual life of the people have been valued. Staff organization has been implemented synchronously. The party has attached great attention to consolidating the organizational apparatus of the Party and State agencies, which are consolidated and arranged in the direction of streamlined, effective, and efficient operation. The Party's cadres have been trained to meet the requirements of their tasks.

In the new situation, to build a socialist rule of law state of the people, by the people, for the people, it is necessary to institutionalize and concretize the ruling role of the Party into a legal system. On the other hand, it is essential to prevent abuse of power in the apparatus of the Party and State. To do this well, it is necessary to build a power control mechanism. The objective of power control is to prevent abuse of position and power to contravene the law, corruption, group interests, and manipulation in cadre work powers and duties to exercise power supervision.

\section{REFERENCES}

Communist Party of Vietnam. (2021). Document of the 13th National Party Congress. Hanoi: National Political Publishing House.

Dong, N. H. (2013). The Party incarnates into the State" in the reform of our Party's ruling method, Legislative Research Journal, 17(249), 3-8.

Dong, N. H. \& Duc, N. H. (2011). Perceiving the concepts of ruling party and leading party in our country, Journal of Political Theory, (6), 35-39.

Hanh, N. T. (2012). Some issues about the ruling party and the opposition party in American political life, Publishing House, Hanoi: Social sciences Publisher

Hien, V. V. (2015). On the Party's governing method. Scientific conference: "Enhancing the ruling position, role and responsibility of the Communist Party of Vietnam in the current situation" organized by the Editorial Department of Journal of Communist and the Quang Ninh Provincial Party Committee, Ha Long, January.

Ho Chi Minh National Academy of Politics. (2018). Textbook of Political Theory on building the Communist Party of Vietnam. Hanoi: Political theory Publishing House.

Huyen, N. V. (2014), Practicing democracy in the condition of one ruling Party, Journal of Party History, 6, 22-31.

Minh, H. C. (1995). Complete Work, Hanoi: National Political Publishing House, Vol.12, p.510. 
Quang, P. N. (2010). A single ruling party - an inevitable product of socio-political reality in Vietnam. Journal of Communist.

Tham, H. B. (2012), Renovating the Party's leadership method in the current ruling Party conditions - the problems raised, Journal of Theoretical Activities, 3(112).

Thang, M. Q. (2011). Some issues about ruling Communist Party of Vietnam in new situation, Journal of Philosophy.

Tiep, N. H. (2017). The ruling Communist Party of Vietnam and the Party's current method of ruling, Journal of Communist.

Trong, N. P. (2004). Building the ruling Party, some practical experiences of innovation in Vietnam, Theoretical workshop between the Communist Party of Vietnam and the Communist Party of China on building the ruling Party, Hanoi: National Political publishing house.

\section{Copyrights}

Copyright for this article is retained by the author(s), with first publication rights granted to the journal. This is an open-access article distributed under the terms and conditions of the Creative Commons Attribution license (http://creativecommons.org/licenses/by/4.0/ 